\title{
Isolation and Characterization of a Novel Bacterium Burkholderia gladioli Bsp-1 Producing Alkaline Lipase
}

\author{
Jing $\mathrm{Zhu}^{1 \dagger}$, Yanjing Liu ${ }^{2 \dagger}$, Yanqin ${ }^{1}$, Lixia Pan $^{1}$, Yi Li ${ }^{1}$, GeLiang ${ }^{1}$, and Qingyan Wang ${ }^{1 *}$ \\ ${ }^{1}$ National Engineering Research Center for Non-Food Biorefinery, State Key Laboratory of Non-Food Biomass and Enzyme Technology, \\ Guangxi Key Laboratory of Bio-refinery, Guangxi Biomass EngineeringTechnology Research Center, Guangxi Academy of Sciences, \\ Nanning 530007, P.R. China \\ ${ }^{2}$ Royal Group Co., Ltd., Nanning 530007, P.R. China
}

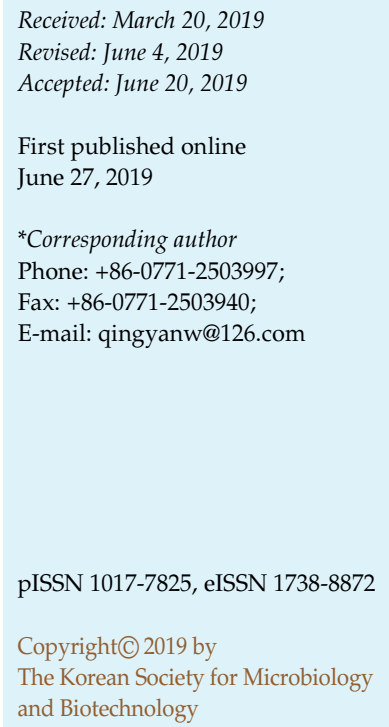

\begin{abstract}
Active lipase-producing bacterium Burkholderia gladioli Bps-1 was rapidly isolated using a modified trypan blue and tetracycline, ampicillin plate. The electro-phoretically pure enzyme was obtained by purification using ethanol precipitation, ion-exchange chromatography, and gel filtration chromatography. The molecular weight was $34.6 \mathrm{kDa}$ and the specific activity was determined to be $443.9 \mathrm{U} / \mathrm{mg}$. The purified lipase showed the highest activity after hydrolysis with $\mathrm{p}-\mathrm{NPC}_{16}$ at a $\mathrm{pH}$ of 8.5 and $50^{\circ} \mathrm{C}$, and the $K_{\mathrm{m}}, k_{\text {cat, }}$ and $k_{\text {cat }} / K_{\mathrm{m}}$ values were $1.05 \mathrm{mM}, 292.95 \mathrm{~s}^{-1}$ and $279 \mathrm{~s}^{-1} \mathrm{mM}^{-1}$, respectively. The lipase was highly stable at $7.5 \leq \mathrm{pH} \leq$ 10.0. $\mathrm{K}^{+}$and $\mathrm{Na}^{+}$exerted activation effects on the lipase which had favorable tolerance to short-chain alcohols with its residual enzyme activity being $110 \%$ after being maintained in $30 \%$ ethanol for $1 \mathrm{~h}$. The results demonstrated that the lipase produced by the strain B. gladioli Bps-1 has high enzyme activity and is an alkaline lipase. The lipase has promising chemical properties for a range of applications in the food-processing and detergent industries, and has particularly high potential for use in the manufacture of biodiesel.
\end{abstract}

Keywords: Burkholderia gladioli Bps-1, alkaline lipase, purification, biocatalysis

\section{Introduction}

Lipase (E.C. 3.1.3) is a special ester hydrolase and biocatalyst that has multiple catalytic functions in the hydrolysis, acidolysis, alcoholysis, ammonolysis and transesterification reactions. Lipases also have wideranging applications in the food processing, paper-making, detergent, and pharmaceutical industries as well. As important metabolic enzymes in organisms, they exist widely in animals, plants and microorganisms. Lipases generally control multiple physiological processes including digestive absorption of organics and metabolism of fat and lipoproteins [1,2].

Lipases from microorganisms are the most widely investigated in comparison to those from animals and plants [3]. Extracellular lipases exhibit different properties produced by a variety of microorganisms and are involved in multiple reaction types including ester synthesis, transesterification, ammonolysis and alcoholysis [4]. These lipases exhibit properties including low substrate requirements, high activity in mild conditions, lack of unnecessary coenzymes and low energy consumption. They have also been widely applied in multiple fields including food processing, textiles, chemical engineering, detergents, biopharmaceuticals and high-molecular polymers [5].

Reports have shown that lipase-producing bacteria comprise approximately 28 genera, including Bacillus, Staphylococcus, Burkholderia, Acinetobacter, Pseudomonas, Saccharomycetes and Actinomycetes and a total of 65 fungal genera have been reported to produce lipase [6]. Lipases produced by bacteria are active in the catalysis of most reaction types, have the highest activity, and are most stable in the organic phase [7].

According to homology of rRNA, Yabuuchi et al. [8] 
partitioned seven kinds of Pseudomonas cepacia into new Burkholderia sp., which belong to the subdivision of the phylum Proteobacteria. Lipases produced by these bacteria have various advantageous properties including favorable temperature stability, tolerance to organic solvents and strict enantio-selectivity. Currently, a growing number of lipases produced by Burkholderia sp. are being reported.

Yang [9] acquired a new type of lipase, SL-4, produced by Burkholderia ubonensis, which is a new member of subfamily I.2 lipases with a molecular weight of $33 \mathrm{kDa}$ and an optimum $\mathrm{pH}$ and temperature of 8.5 and $65^{\circ} \mathrm{C}$, respectively. The lipase from Burkholderia sp. EQ3 purified by Pakpimol shows maximum activity at a $\mathrm{pH}$ of 7.0 7.5 and a temperature of $30^{\circ} \mathrm{C}$. It could be reserved for $1 \mathrm{~h}$ at $\mathrm{pH}$ of 5.0 8.0 with the temperature ranging between $30^{\circ} \mathrm{C} \sim 55^{\circ} \mathrm{C}$. The purified lipase EQ3 still exhibited more than $80 \%$ activity in $25 \%$ isopropanol [10].

Xie [11] isolated the new bacterium Burkholderia cepacia RQ3 using polar and non-polar organic solvents (DMSO and methylbenzene) as a screening stress. The bacterium was resistant to organic solvents and the lipase RQ3 had an optimum $\mathrm{pH}$ and temperature of 9.0 and $40^{\circ} \mathrm{C}$, respectively, and showed favorable stability across a wide $\mathrm{pH}$ range (6.0 10.0) and at temperatures lower than $50^{\circ} \mathrm{C}$. In addition, a broader working $\mathrm{pH}$ and higher thermostability of the lipase were achieved by immobilization [12]. Wang [13] used $\mathrm{Fe}_{3} \mathrm{O}_{4} @$ chitosan nanoparticles for covalent immobilization of lipase from Thermomyces lanuginosus by chemical conjugation after electrostatic entrapment (CCEE), and the immobilized lipase retained $70 \%$ of its initial activity after ten cycles. $\mathrm{Xu}$ [14] reported that CLEAs of lipase prepared by using p-benzoquinone as a crosslinking agent could retain $75.18 \%$ of the initial activity of the biocatalyst.

In the present study, Burkholderia sp. Bps-1 was isolated by addition of small amounts of antibiotics to the modified trypan blue and tetracycline, ampicillin (TB-TA) plate considering the essential metabolite and the drug resistance of Burkholderia sp. The strain was identified as Burkholderia gladioli through 16S rDNA sequencing and the Microlog Microbial Identification System. The alkaline lipase produced by the isolate Bps-1 was purified through ethanol precipitation, anion exchange chromatography and gel filtration chromatography. Chemical characterization of the purified Bps-1 lipase showed that the molecular weight, optimum $\mathrm{pH}$ and temperature were $34.6 \mathrm{kDa}, 8.5$ and $50^{\circ} \mathrm{C}$, respectively. The lipase Bps-1 exhibited high stability at $\mathrm{pH}$ of 7.5 to 10.0 and a favorable tolerance to short-chain alcohols.

\section{Materials and Methods}

\section{Specimens}

Putrid onion specimens were obtained from a supermarket in Nanning, the Guangxi Zhuang Autonomous Region, China.

\section{Culture Medium}

Sterile TB-TA directional screening plate composed of glucose ( $2 \mathrm{~g} / \mathrm{l})$, L-asparagine $(1.0 \mathrm{~g} / \mathrm{l}), \mathrm{NaHCO}_{3}(0.5 \mathrm{~g} / \mathrm{l}), \mathrm{KH}_{2} \mathrm{PO}_{4}(0.25 \mathrm{~g} / \mathrm{l})$, $\mathrm{MgSO}_{4} \cdot 7 \mathrm{H}_{2} \mathrm{O}(0.05 \mathrm{~g} / \mathrm{l})$, trypan blue $(0.05 \mathrm{~g} / \mathrm{l})$, tetracycline $(0.01 \mathrm{~g} / \mathrm{l})$, ampicillin $(0.15 \mathrm{~g} / \mathrm{l})$ and agar powder $(15 \mathrm{~g} / \mathrm{l})$ was used.

The identification plate of Rhodamine $\mathrm{B}$ comprised peptone $(5 \mathrm{~g} / \mathrm{l})$, yeast extract $(3 \mathrm{~g} / \mathrm{l}), \mathrm{NaCl}(8 \mathrm{~g} / \mathrm{l}), 4 \mathrm{ml}$ Rhodamine B solution $(0.1 \%, \mathrm{w} / \mathrm{v})$ and $10 \mathrm{ml}$ soybean oil emulsion. The soybean oil emulsion was prepared by mixing $3 \mathrm{ml}$ soya-bean oil with $9 \mathrm{ml}$ polyvinyl alcohol $(2 \%, \mathrm{w} / \mathrm{v})$ for $10 \mathrm{~min}$ using an emulsifying machine. After settling for $5 \mathrm{~min}$, emulsification continued until delamination disappeared.

Culture medium of seed solution: LB culture medium was made from Tryptone $10 \mathrm{~g} / \mathrm{l}$, yeast extract $5 \mathrm{~g} / \mathrm{l}, \mathrm{NaCl} 10 \mathrm{~g} / \mathrm{l}$.

Fermentation medium was composed of $1.0 \%(\mathrm{v} / \mathrm{v})$ saccharose, $0.25 \%(\mathrm{v} / \mathrm{v})$ palm oil, $1.5 \%(\mathrm{w} / \mathrm{v})$ peptone, $0.2 \%(\mathrm{w} / \mathrm{v}) \mathrm{KH}_{2} \mathrm{PO}_{4}$ and $0.05 \%(\mathrm{w} / \mathrm{v}) \mathrm{MgSO}_{4} \cdot 7 \mathrm{H}_{2} \mathrm{O}$.

\section{Isolation and Identification of Burkholderia sp.}

Exactly, $5 \mathrm{~g}$ of shredded putrid onion was suspended into $100 \mathrm{ml}$ of normal saline and the solution was spread on TB-TA plate at a concentration $10^{-3}-10^{-4}$ times that of the suspension liquid obtained by gradient dilution. The colonies on the plates with the modified TB-TA medium were then streaked onto the identification plate of Rhodamine B for lipolytic bacteria and cultured at $30^{\circ} \mathrm{C}$ for 2 days. A single strain was then obtained by purifying the bacterial colonies with a ratio of the radius of a transparent circle to the radius of colony greater than 2 through plate streaking. The isolated strain was morphologically characterized and identified using the Microlog Microbial Identification System (Biolog, USA) and 16S rDNA sequential analysis.

\section{Culture Conditions for Producing Lipase}

Some colonies from an LB agar plate were inoculated into the fermentation medium and incubated at $30^{\circ} \mathrm{C}$ until the log phase of the culture was obtained. Exactly, 1\% (v/v) of this culture was inoculated into the fermentation medium and incubated for $72 \mathrm{~h}$ at $30^{\circ} \mathrm{C}$. Subsequently, the broth was centrifuged for $10 \mathrm{~min}$ at $8,000 \times g$ and the supernatant was collected for the use as a crude enzyme specimen.

\section{Lipase Activity Assay}

Solution A: $16.5 \mathrm{mmol} / 1$-nitrophenol palmitate $\left(\mathrm{pNPC}_{16}\right)$ solution in isopropanol. Solution B: Tris- $\mathrm{HCl}$ buffer solution $(\mathrm{pH}=9.0)$ of $0.05 \mathrm{~mol} / 1$ using $2 \%(\mathrm{w} / \mathrm{v})$ Triton $\mathrm{X}-100$ and $0.1 \%$ $(\mathrm{w} / \mathrm{v})$ Arabic gum. 
The reaction system was described as follows: $45 \mu$ l of solution A was mixed with $405 \mu$ l of solution B after pre-heating at $50^{\circ} \mathrm{C}$ for $5 \mathrm{~min}$, the diluted liquid enzyme sample was reacted for $10 \mathrm{~min}$ and a spectrophotometer method was used to measure the amount of liberated $\mathrm{pNPC}_{16}$ at a wavelength of $405 \mathrm{~nm}$. The reaction was stopped by adding $500 \mu 1$ of $10 \%(\mathrm{w} / \mathrm{v})$ trichloroacetic acid: $1 \mathrm{ml}$ of $0.5 \mathrm{M} \mathrm{Na}_{2} \mathrm{CO}_{3}$ was then added to adjust the $\mathrm{pH}$ so that the reaction system was alkaline. The lipase activity unit $\mathrm{U}$ was defined as the amount of lipase consumed by the decomposition of $\mathrm{pNPC}_{16}$ for the production of $1 \mu \mathrm{mol}$ of nitrophenol per minute. All experiments were performed in triplicate [15-17].

\section{Purification of Lipase}

The crude enzyme was freeze-dried in a vacuum freeze-drying system. Exactly, $6 \mathrm{~g}$ of the freeze-dried crude enzyme was dissolved in $2 \mathrm{ml}$ of $0.05 \mathrm{~mol} / \mathrm{l}$ piperazine buffer solution at a $\mathrm{pH}$ of 9.7. The mixture was precipitated by adding ethanol to a final concentration of $60 \%(\mathrm{w} / \mathrm{v})$, after which the mixture was centrifuged for $10 \mathrm{~min}$ at $8,000 \times g$ to remove unspecific proteins. The target protein was precipitated using ethanol with a final concentration of $95 \%(\mathrm{v} / \mathrm{v})$ followed by centrifugation at $8,000 \times g$ for $10 \mathrm{~min}$. Precipitations were dissolved in $0.05 \mathrm{~mol} / 1$ piperazine buffer solution at $\mathrm{pH}$ of 9.7 to obtain the preliminarily purified enzyme which was further purified through HiTrap Q $(5 \mathrm{ml})$ and Superdex 75 gel filtration columns $(100 \times 1.2 \mathrm{~cm})$.

\section{Effect of Temperature on Activity and Stability}

The relative lipase activity was measured at different temperatures $\left(30 \sim 75^{\circ} \mathrm{C}\right)$ to obtain the optimum reaction temperature. Residual activity was tested after the diluted enzyme was maintained for 1 hour at temperatures ranging from 25 to $85^{\circ} \mathrm{C}$. The thermal stability of the lipase was analyzed by comparison with the untreated control enzyme.

\section{Effect of pH on Activity and Stability}

The relative lipase activity was measured and the optimum $\mathrm{pH}$ for reaction was determined after the substrate- $\mathrm{pNPC}_{16}$ was dissolved in buffer solution at different $\mathrm{pH}$ values (2.2-10.0). After the lipase was diluted using the buffer solution at a $\mathrm{pH}$ ranging from 2.2 to 12.0 , it was maintained for $24 \mathrm{~h}$ at $25^{\circ} \mathrm{C}$ and then the residual activity was measured. The $\mathrm{pH}$ stability of lipases was analyzed by comparison with the untreated control enzyme without the addition of buffer.

\section{Effect of Organic Solvents on Lipase Activity}

The lipase was diluted using Tris- $\mathrm{HCl}$ buffer solution at a $\mathrm{pH}$ of 8.5. n-heptane (0.2), n-hexane (0.06), cyclohexane (0.1), methanol (5.1), ethanol (5.2), isopropanol (3.9), ethyl acetate (4.4), acetone (5.1) and methylbenzene (2.4) were separately added so that the final concentration of organic solvent was $30 \%(\mathrm{v} / \mathrm{v})$. After the mixture was maintained for 1 hour at an oscillation rate of $300 \mathrm{r} / \mathrm{min}$ at $50^{\circ} \mathrm{C}$, the relative lipase activity was determined. By comparing the enzyme with and without adding the organic solvent, the effect of organic solvent on the lipase was calculated.

\section{Effect of Metallic Ions and Protease Inhibitor on Enzyme activity}

The lipase was maintained in a solution containing various metallic ions, $\beta$-mercaptoethanol, EDTA, SDS and DDT at the final concentration of $10 \mathrm{mmol} / 1$ after being diluted using Tris- $\mathrm{HCl}$ buffer solution at a $\mathrm{pH}$ of 8.5. After the mixture was stored for $1 \mathrm{~h}$ at an oscillation rate of $300 \mathrm{r} / \mathrm{min}$ at $30^{\circ} \mathrm{C}$, the relative lipase activity was obtained. The effects of metallic ions and protein inhibitors on the lipase were investigated by comparing the enzyme with the control without adding organic solvents.

\section{Substrate Specificity and Kinetic Analysis}

Certain amounts of p-nitrophenol fatty acid esters $\left(C_{2}, C_{4}, C_{8}\right.$, $\mathrm{C}_{10}, \mathrm{C}_{12}, \mathrm{C}_{14}, \mathrm{C}_{16}$, and $\mathrm{C}_{18}$ ) with different carbon-chain lengths were weighed as substrates with a final concentration of $16.5 \mathrm{mmol} / \mathrm{l}$. The relative activities of the lipase on various substrates were detected at a $\mathrm{pH}$ of 8.5 and temperature of $50^{\circ} \mathrm{C}$. Data were normalized as a percentage of the largest relative lipase activity [18].

The four substrates $\left(C_{12}, C_{14}, C_{16}\right.$, and $\left.C_{18}\right)$ with the highest hydrolytic activities were taken and the activities of the lipase were measured when the concentrations of the substrates were $0.2,0.3,0.4,0.5,0.625,1.0,2.0$, and $5.0 \mathrm{mmol} / 1$. Using non-linear regression (OriginPro8.5), the kinetic constants $\left(K_{\mathrm{m}}\right.$ and $\left.V_{\max }\right)$ and the catalytic constants $\left(k_{\mathrm{cat}}\right.$ and $\left.k_{\mathrm{cat}} / K_{\mathrm{m}}\right)$ of the lipase were calculated.

\section{Results}

\section{Screening and Identification of Strains}

At present, research into Burkholderia sp. is increasingly widespread and the Burkholderia cepacia complex (BCC) has been most intensively studied [19]. Numerous methods for isolating bacterial genera are known, amongst which the most rapid is the plate screening method, which exhibits a directional screening rate of up to $90 \%$ using special metabolites and drug resistance. Owing to BCC belonging to Burkholderia sp., the growth conditions, physiological characterization and drug resistance of the two substances show many similarities. Ampicillin and nystatin (TB-TA plate) with a certain concentration were added into the selected plate TB-T of BCC and the proportion of Lasparagines (only nitrogen source) was improved. On this basis, the culture medium was named TB-TA, and applied to directionally isolate the Burkholderia sp. strain. Bacterial colonies grew up on the plate after culturing the strain for 3-4 days at $30^{\circ} \mathrm{C}$.

The developed bacterial colonies were dripped on the Rhodamine B plate for identification as shown in Fig. 1, showing that the bacterial colonies with transparent circles 


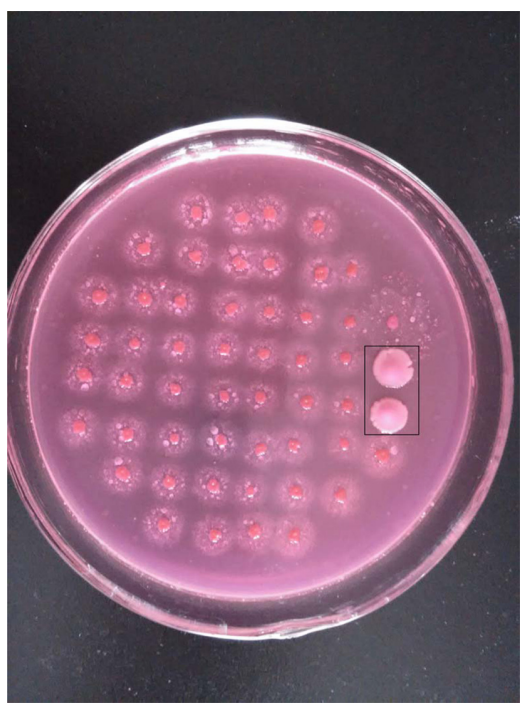

Fig. 1. Production of lipases by Burkholderia sp. complex strains on the selective screening medium for lipase activity. Only two colonies (marked with a black frame) did not possess sufficient activity to hydrolyze olive oil on the olive oil-rhodamine B plate.

accounted for more than 95\%. The single strain was obtained after the bacterial colonies with a radius ratio of the transparent circle to colony of greater than 2 were purified through plate streaking. The activities of the lipase of 13 strains subjected to the liquid culture were measured and the strain with the highest activity was named Bps-1. The strain was morphologically characterized as a Gramnegative bacterium, which forms faint yellow, round, smooth and moist bacterial colonies with regular sides on LB medium and produces xanthein after growth for 2 days. The bacterium is aerobic and motile, has rod-like cells without spores and grows at $30-35^{\circ} \mathrm{C}$ and $\mathrm{pH}$ of $5.0-8.0$ (optimal pH of 6.5-7.5). The bacterium was identified as Burkholderia 25gladioli using the Biolog system (the value of SIM was 0.575 after being cultured for $24 \mathrm{~h}$ ).

The length of $16 \mathrm{~S}$ rDNA gene of the bacterium Bps-1 was determined to be 1,500 bp by PCR amplification. Sequencing showed that the sequence had 1,493 bp and was deposited in NCBI after biting off the chimera sequence (accession number of the sequence: MF618254). The comparison results of BLAST revealed that the sequence exhibited the highest similarity with 16S rDNA sequence of Burkholderia gladioli. Using a phylogenetic tree (shown in Fig. 2) designed using MEGA6.0, it can be seen that the strain belonged to the same population as the Burkholderia gladioli strain GRBB 15043. Through the analysis of the morphological features and identification using the Biolog system, it was verified that the strain was Burkholderia gladioli. In summary, the rapid isolation of the Burkholderia sp. strain was achieved using a selection plate of TB-TA.

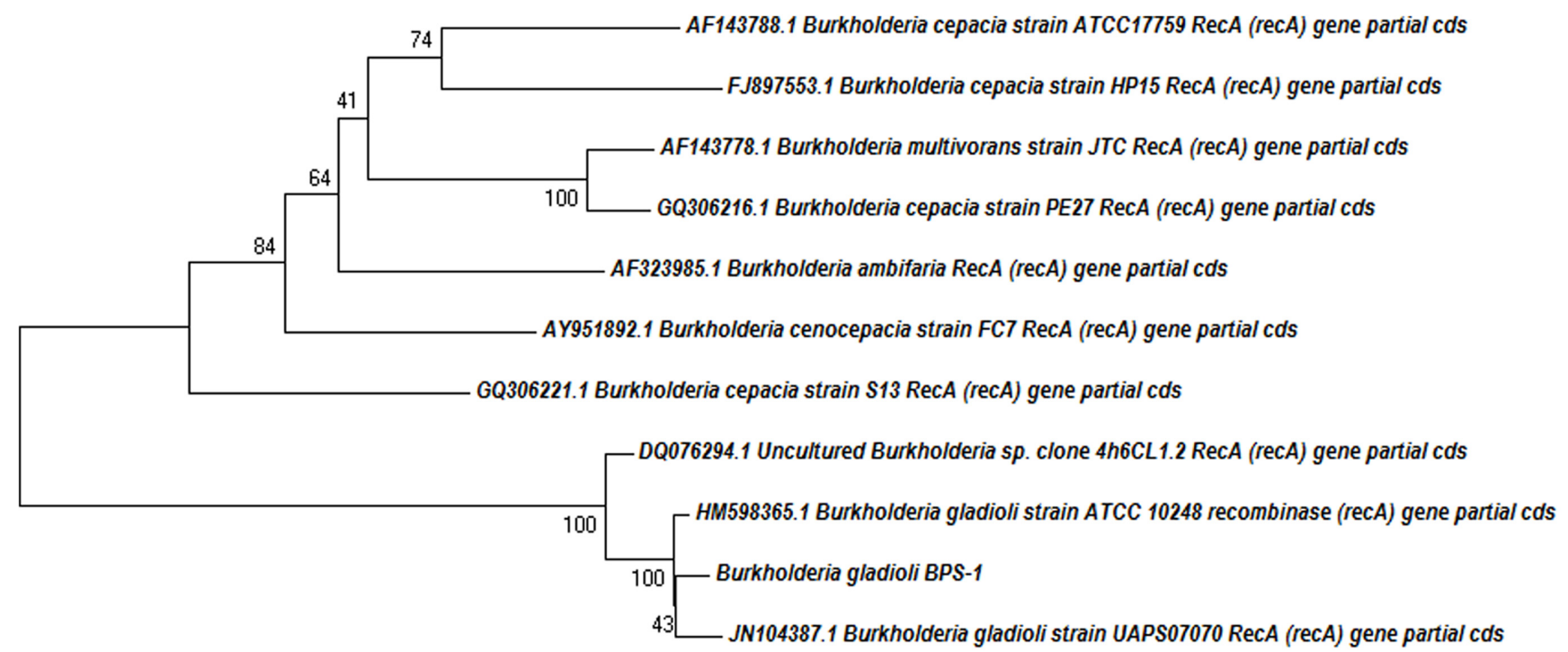

\subsection{0}

Fig. 2. Phylogenetic tree based on the $16 \mathrm{~S}$ rDNA gene sequence of isolated B. gladioli Bps-1 and other related species. Levels of bootstrap support (percent, $n=1,000$ ) were indicated at nodes. The scale bar represents 0.001 nucleotide substitutions per position. 


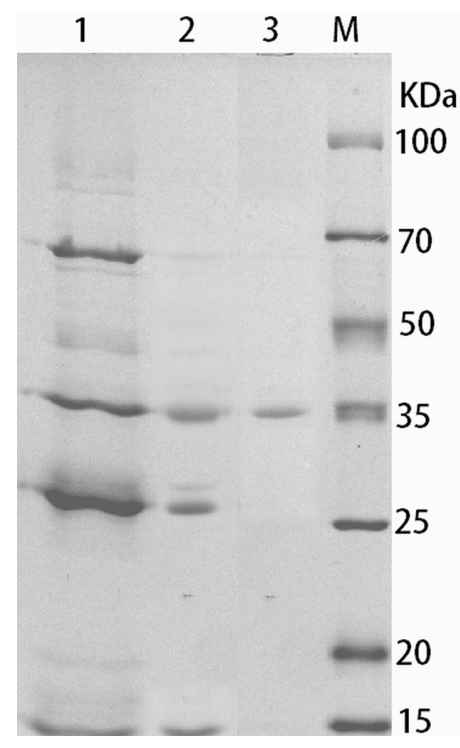

Fig. 3. SDS-PAGE of lipase B. gladioli Bps-1.

1: Protein specimen through ethanol precipitation; 2: specimen purified through HiTrap Q; 3: specimen purified through Superdex 75; M: molecular weight markers.

\section{Protein Purification and Measurement of Molecular Weights}

The lipase specimens were obtained from the fermentation supernatant of B. gladioli Bps-1 and were purified through freeze-drying, ethanol precipitation, HiTrap Q, and Superdex 75. The purified lipase was a single band product with an apparent molecular mass of $34.6 \mathrm{kDa}$ according to SDS-PAGE (Fig. 3). The yield of the lipase was $0.029 \%$ after purification (purification fold: 4.57) through the above steps, and the specific activity of the purified lipase in the hydrolysis of $\mathrm{pNPC}_{16}$ was $443.90 \mathrm{U} / \mathrm{mg}$ (as shown in Table 1).

\section{Effect of Temperature on Activity and Thermal Stability}

The optimum temperature and temperature stability of the lipase are shown in Fig. 4A. The optimal reaction temperature of the lipase was $50^{\circ} \mathrm{C}$ and the purified lipase exhibited favorable thermal stability at temperatures between $25-70^{\circ} \mathrm{C}$. The residual activity comprised $50 \%$ of
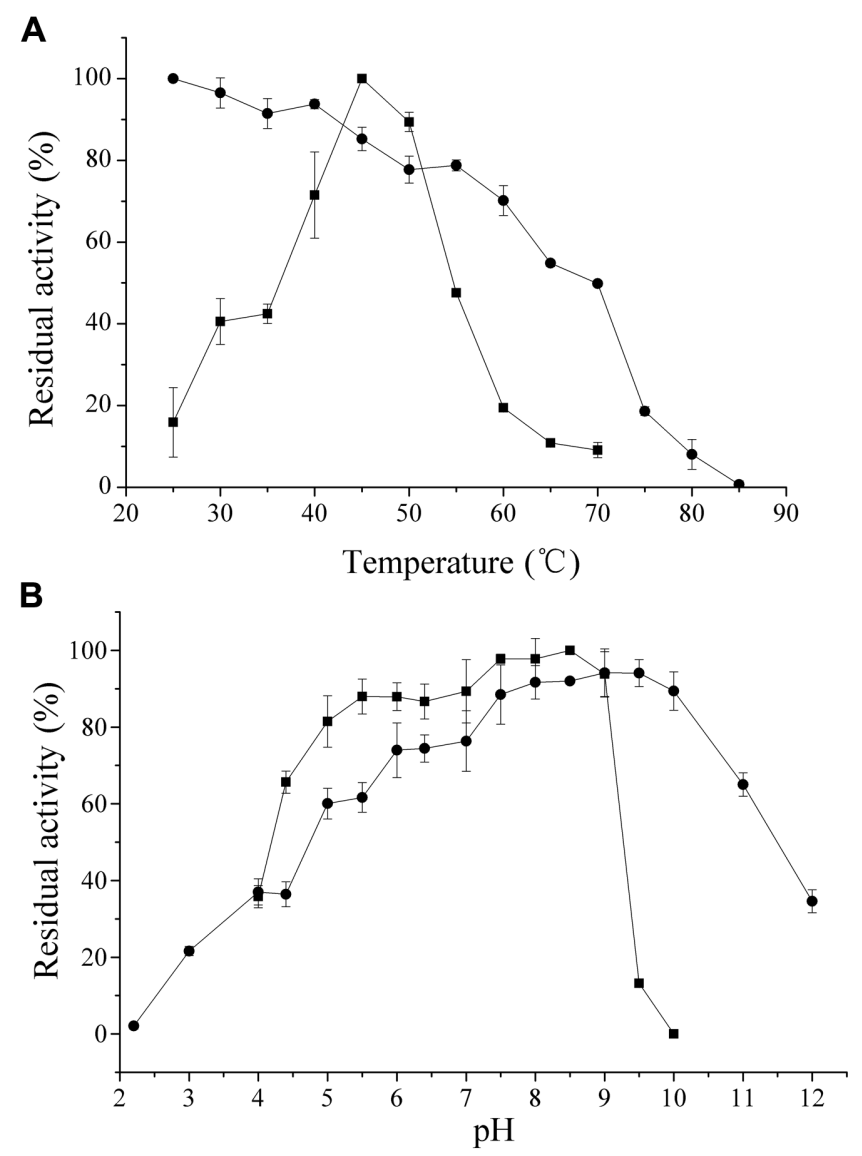

Fig. 4. Effect of temperature and $\mathrm{pH}$ on the activity (square) and stability (circles) of lipase Bps-1.

(A) The effects of temperature on the activity (square) and stability (circles) of lipase Bps-1. (B) The effect of $\mathrm{pH}$ on the activity (square) and stability (circles) of lipase from Bps-1.

the primary activity after the lipase was treated for $1 \mathrm{~h}$ at $70^{\circ} \mathrm{C}$. It has been reported that lipases produced by Gramnegative bacteria showed unsatisfactory thermal stability. For example, the lipase EQ3 was active at $30 \sim 55^{\circ} \mathrm{C}$ and reached a peak at $30^{\circ} \mathrm{C}$. The enzyme activity at $55^{\circ} \mathrm{C}$ still accounted for $80 \%$ of that at $30^{\circ} \mathrm{C}$ while it significantly decreased at $65^{\circ} \mathrm{C}$. The extracellular lipases from Pseudomonas fluorescens MTCC 2421 exhibited enzyme activity at 35 to

Table 1. Summary of the purification of lipase from B. gladioli Bps-1.

\begin{tabular}{|c|c|c|c|c|c|}
\hline & Total protein (mg) & Total activity (U) & Specific activity (U/mg) & Purification (fold) & Yield (\%) \\
\hline Crude enzyme & 6,000 & $582,680.2$ & 97.11 & 1 & 100 \\
\hline Ethanol precipitation & 567 & $58,707.18$ & 103.54 & 1.07 & 10.1 \\
\hline HiTrap Q & 1.36 & 357.99 & 263.23 & 2.71 & 0.061 \\
\hline Superdex 75 & 0.38 & 168.68 & 443.90 & 4.57 & 0.029 \\
\hline
\end{tabular}


$50^{\circ} \mathrm{C}$, which increased to a maximum at $40^{\circ} \mathrm{C}$, whilst at $50^{\circ} \mathrm{C}$ decreased by $44 \%$ [20].

In addition, the lipase from Burkholderia sp. HY-10 only maintained $50 \%$ activity after being cultured for $30 \mathrm{~min}$ at $60^{\circ} \mathrm{C}$ [21]. As the stability of enzymes at higher temperatures could greatly increase reaction rates, the thermal stability of Bps-1 lipase was an ideal characteristic.

\section{Effect of $\mathrm{pH}$ on Activity and Stability}

The optimum $\mathrm{pH}$ and $\mathrm{pH}$ stability of the purified lipase are illustrated in Fig. 4B, and as shown in the figure, the optimum $\mathrm{pH}$ of the lipase was 8.5. The purified lipase exhibited strong stability in an alkaline environment, particularly across a $\mathrm{pH}$ range from 7.5 to 10.0 , and still had more than $85 \%$ residual activity after being maintained for $24 \mathrm{~h}$ at $\mathrm{pH} 10$, indicating that the enzyme was an alkaline lipase. Reports have shown that most lipases from Burkholderia sp. presented the optimum activity under neutral and alkaline conditions. For instance, the optimum $\mathrm{pH}$ of the lipase from Burkholderia sp. EQ3 was in the range of 7.0-7.5 with the lipase having greater than $80 \%$ activity at the $\mathrm{pH}$ of $6.0-8.0$ [10]. In contrast, the lipase from B. cepacia LP08 exhibited activity across a broader $\mathrm{pH}$ range of 5.0 -10.6 and reached maximum activity peak at $\mathrm{pH} 9.0$ [22]. Additionally, the lipase from B. multivorans PSUAH130 could retain more than $80 \%$ activity at a $\mathrm{pH}$ of $7.5-$ 10.0 [23]. This may be because the structures of the Burkholderia sp. producing lipases were more suitable for approaching the oil-water interface in an alkaline environment and then opening the cover which impeded the active sites and so the hydrolysis energy declined. As the key to applying lipases in various technological processes such as detergent and leather manufacturing lies in the stability of the enzymes in alkaline environments, Bps-1 is seen as an ideal enzyme for industrial applications.

\section{Effect of Organic Solvents on Enzyme Activity}

Lipases show high catalytic activities in organic solvents and organic solvent-bearing environments. The yield of biodiesel can be significantly improved using lipases that are tolerant to organic solvents, particularly methanol and ethanol. Exploring the tolerance of lipases to organic solvents is an important area of research. In this study, the influences of nine polar and non-polar organic solvents (polar indices 0.06 5.2) on the activity of lipase Bps-1 were investigated, as shown in Fig. 5A. The enzyme exhibited a favorable tolerance to short-chain alcohols with a large polar index and the enzyme activity presented no significant changes $(90 \%, 110 \%)$ after being maintained for
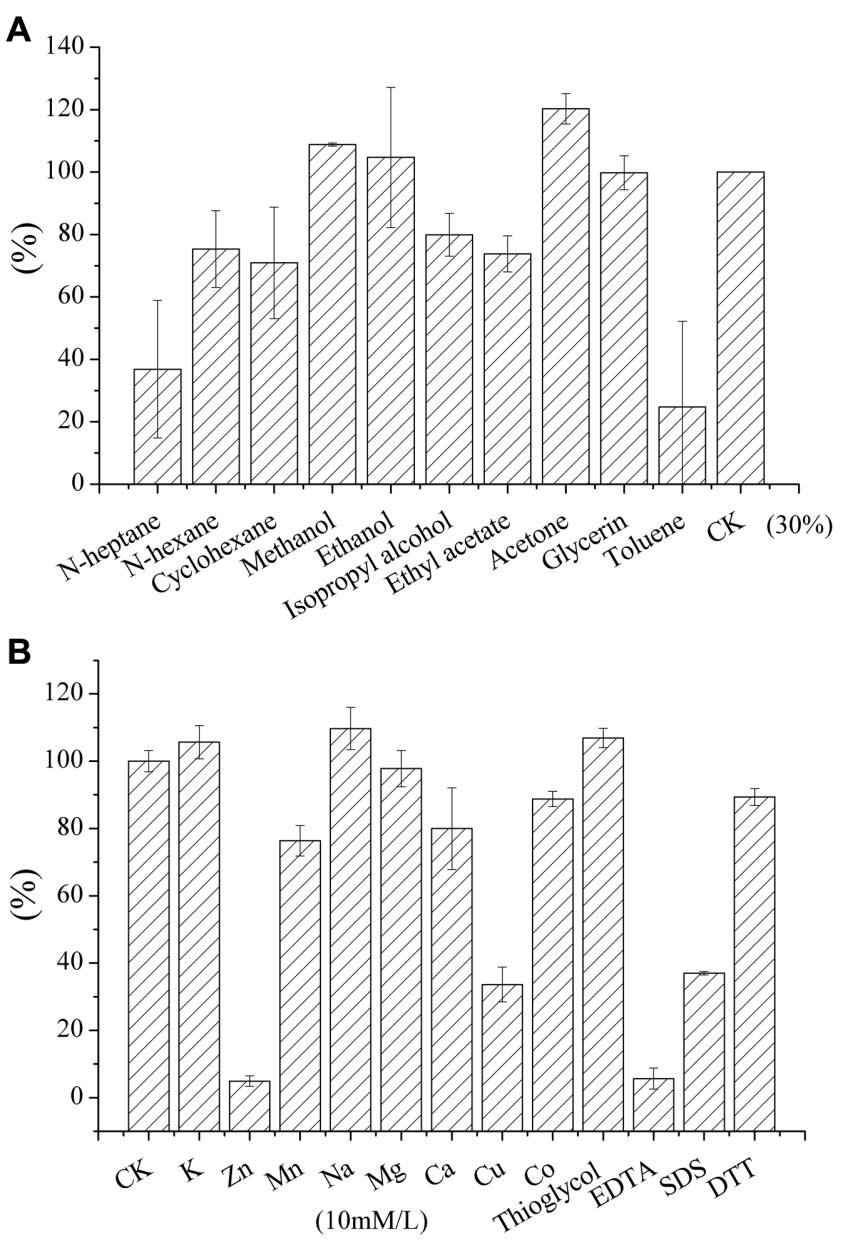

Fig. 5. Effect of organic solvents,metallic ions and protein inhibitors on the activity of lipase Bps-1.

(A) The effect of organic solvents on the activity of lipase Bps-1. (B) The effects of metallic ions and protein inhibitors on the activity of lipase Bps-1.

$1 \mathrm{~h}$ in $30 \%(\mathrm{v} / \mathrm{v})$ methanol and ethanol. However, solvents with low polar indices (methylbenzene, n-heptane, cyclohexane and n-hexane) exhibited an inhibitory effect on Bps-1, whilst acetone and glycerinum exerted an activation effect.

Most lipases show decreasing activity or are inactive in organic solvent environments due to the changes in the secondary structures of the enzyme molecules under the influence of molecules of organic solvents. This triggers a change in enzyme activity in the organic solvents which is mainly shown as conformational changes in the contents of $\beta$-sheet and $\alpha$-helix. Currently, only a small quantity of lipases from Burkholderia sp. show levels of tolerance to organic solvents. For example, the lipase from B. cepacia S31 retains $43 \%$ and $71 \%$ of residual activity after separately 
being maintained for $6 \mathrm{~h}$ in $25 \%$ ethanol and acetonitrile [24]. The lipase SL-4 from Burkholderia ubonensis maintained residual activity taking up $92 \sim 147 \%$ of the primary activity after being held for $2 \mathrm{~h}$ in $15 \%(\mathrm{v} / \mathrm{v})$ isopropanol, acetonitrile, acetone, tert-butyl alcohol and chloroform. However, the residual activity remarkably decreased to $28 \% \sim 70 \%$ of the primary activity after holding the lipase in $30 \%$ (v/v) xylene solution [22]. The lipases with high tolerance to organic solvents have favorable stability and catalytic activities, and also can influence the enantioselectivity, thereby showing more significant value for industrial applications.

\section{The Effect of Metallic Ions and Protein Inhibitors on Enzyme Activity}

The influences of different metallic ions and inhibitors on lipase activity are illustrated in Fig. 5B. Most previous studies indicate that $\mathrm{Ca}^{2+}$ exerted an activation effect on lipases. For example, the lipases from P. aeruginosa LX1 [25], Pseudomonas DMVR46 [26], B. cepacia ATCC25416 [27] and B. multivorans V2 [28] all exhibited strong activities due to presence of $\mathrm{Ca}^{2+}$. However, $\mathrm{Ca}^{2+}$ had an inhibitory effect on B. gladioli Bps-1. The residual activity took up $80 \%$ of the primary activity after the Bps-1 was stored in $10 \mathrm{mmol}$ of $\mathrm{Ca}^{2+}$ solution for 1 hour. In contrast, $\mathrm{K}^{+}$and $\mathrm{Na}^{+}$ions were found to enhance enzyme activity. The residual activity accounted for $105 \%$ and $110 \%$ after the lipase Bps-1 was separately preserved in $\mathrm{K}^{+}$and $\mathrm{Na}^{+}$solutions for $1 \mathrm{~h}$. This may be because the active site of B. gladioli Bps-1 was different from those of the above lipases.

In addition, $\mathrm{Zn}^{2+}$ and $\mathrm{Cu}^{2+}$ had strong inhibitory effects on Bps-1 lipase: residual activities of Bps-1 lipase only took up $5 \%$ and $30 \%$ of the initial enzyme activity respectively. The results are in agreement with the reports of Rahman et al. [29], showing that transition metal ions at a concentration of $10 \mathrm{mM}$ could enhance the interactions between the ions and the surface amino acids of charged side-chain radicals which significantly influenced the ionization of some amino acid residues, and so lipases became instable due to ion toxicity.

The metal-chelator EDTA (10 mM) had a strong inhibitory

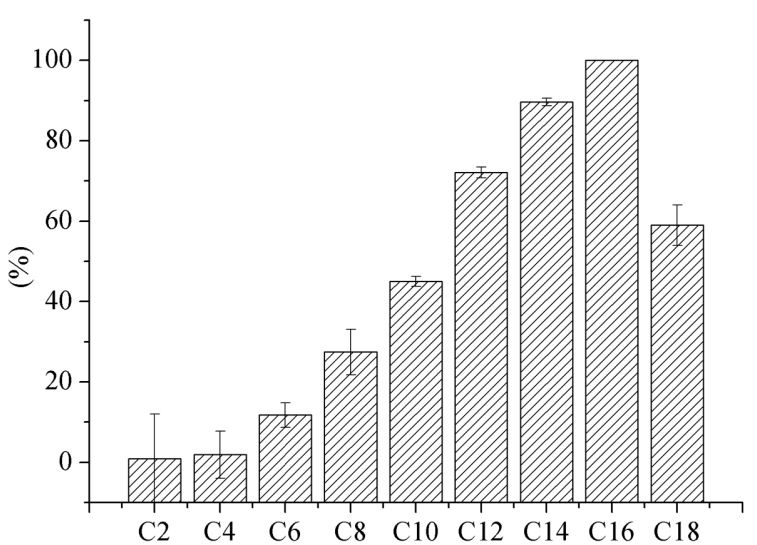

Fig. 6. Substrate specificity of lipase Bps-1.

effect on B. gladioli Bps-1 lipase. Only 10\% residual activity remained after the lipase was maintained for $1 \mathrm{~h}$ in EDTA, indicating that the lipase was a metallo-enzyme containing disulfide bonds. However, $\beta$-mercaptoethanol $(10 \mathrm{mM})$ had no influence on enzyme activity. It is therefore assumed that the disulfide bond in the protein structure of the lipase was not in the active site [30]. Additionally, the inhibitor SDS showed a significant inhibitory effect on the enzyme whilst DTT had no significant effect on activity.

\section{Substrate Specificity and Kinetic Analysis}

The enzyme activities of the lipase were measured separately using $\mathrm{C}_{2}, \mathrm{C}_{8}, \mathrm{C}_{10}, \mathrm{C}_{12}, \mathrm{C}_{14}, \mathrm{C}_{16}$, and $\mathrm{C}_{18}$ as substrates to determine the hydrolysis capacity of the lipase on the fatty acid with different lengths of carbon chains. As shown in Fig. 6, the lipase showed differential hydrolysis capacities on the substrates. Enzyme activity was lower during the measurement using $\mathrm{C}_{2}, \mathrm{C}_{8}$, and $\mathrm{C}_{10}$ as substrates whilst higher enzyme activity was observed using $\mathrm{C}_{12}-\mathrm{C}_{18}$ as substrates. These data imply that Bps-1 exhibited a strong hydrolysis capacity on medium- and long-chain fatty acids. Bps-1 was therefore a true lipase rather than an esterase.

The $K_{\mathrm{m}}, V_{\max }$ and $k_{\text {cat }}$ values in the hydrolysis of the substrates $C_{12}-C_{18}$ using Bps-1 were separately measured and summarized in Table 2. Bps-1 exhibited the strongest

Table 2. Kinetic parameters of lipase Bps-1 for p-nitrophenyl esters.

\begin{tabular}{|c|c|c|c|c|}
\hline Substrates & $V_{\max }\left(\mu \mathrm{mol} \mathrm{min}{ }^{-1} \mathrm{mg}^{-1}\right)$ & $K_{\mathrm{m}}(\mathrm{mM})$ & $k_{\text {cat }}\left(\mathrm{s}^{-1}\right)$ & $k_{\text {cat }} / K_{\mathrm{m}}\left(\mathrm{s}^{-1} \mathrm{mM}^{-1}\right)$ \\
\hline $\mathrm{C}_{12}$ & 260.60 & 2.01 & 158.97 & 79.09 \\
\hline $\mathrm{C}_{14}$ & 411.02 & 1.35 & 250.72 & 185.72 \\
\hline $\mathrm{C}_{16}$ & 480.25 & 1.05 & 292.95 & 279 \\
\hline $\mathrm{C}_{18}$ & 226.28 & 1.65 & 138.03 & 83.66 \\
\hline
\end{tabular}


hydrolysis capacity on the substrate $C_{16}$. The enzyme specific activity reached $480.25 \mathrm{U} / \mathrm{mg}$ after the substrate $\mathrm{C}_{16}$ was hydrolyzed for $10 \mathrm{~min}$ in the $50 \mathrm{mM} / \mathrm{L}$ Tris- $\mathrm{HCl}$ buffer system at a $\mathrm{pH}$ of 8.5 at $50^{\circ} \mathrm{C}$. Bps-1 had a strong affinity with $\mathrm{C}_{16}\left(K_{\mathrm{m}}=1.05\right)$. However, enzyme catalysis was a process during which the reaction rate increased with growing substrate concentration and reached the highest when all active sites of the enzyme were filled with substrates. As the specific activity did not provide an accurate enzyme reaction efficiency model for industrial applications, it was necessary to further calculate $k_{\text {cat }} / K_{\mathrm{m}}$ as the catalytic efficiency. As shown in the Table 2, the catalytic efficiency $\left(k_{\text {cat }} / K_{\mathrm{m}}\right)$ of the lipase Bps-1 gradually rose to the peak from $\mathrm{C}_{12}\left(79.09 \mathrm{~s}^{-1} \mathrm{mM}^{-1}\right)$ to $\mathrm{C}_{16}\left(279 \mathrm{~s}^{-1} \mathrm{mM}^{-1}\right)$ and then reduced to $83.66 \mathrm{~s}^{-1} \mathrm{mM}^{-1}$ when $\mathrm{C}_{18}$ was used as a substrate.

Due to different varieties of enzymes, substrates, and values of $K_{\mathrm{m}}$, the catalytic efficiency $\left(k_{\text {cat }} / K_{\mathrm{m}}\right)$ also varies. The value of $k_{\text {cat }} / K_{\mathrm{m}}$ is generally between $10^{4}$ to $1 \mathrm{~s}^{-1} \mathrm{mM}^{-1}$. It was reported by Niu Yu [31] that the lipase TLip produced by Thauera sp. had a catalytic efficiency $\left(k_{\text {cat }} / K_{\mathrm{m}}\right)$ of $71.4 \pm 2.4 \mathrm{mM}^{-1} \mathrm{~s}^{-1}$ when pNPD $\left(\mathrm{C}_{12}\right)$ was used as the substrate. Li Ai [32] isolated a halophilic lipase (LipS2) produced by Chromohalobacter canadensis which also presented better catalytic activity for medium- and longchain $\left(>\mathrm{C}_{12}\right)$ triglycerides. When p-NPP was used as the substrate, the values of $k_{\text {cat }}$ and $K_{\mathrm{m}}$ were $10.8 \mathrm{mM}$ and $13.2 \mathrm{~S}^{-1}$, and therefore the catalytic efficiency $\left(k_{\text {cat }} / K_{\mathrm{m}}\right)$ was $73.26 \mathrm{M}^{-1} \mathrm{~S}^{-1}$. The values of $K_{\mathrm{m}}$ and the catalytic efficiency $\left(k_{\text {cat }} / K_{\mathrm{m}}\right)$ of the lipase Bps-1 isolated in this research were both at a moderate level, which was probably because B. gladioli Bps-1 thrived in suitable conditions without long-term extreme environmental stress; however, it could be modified in future research through genetic cloning and expression as well as mutation. For example, Wang [33] found that the value of $k_{\mathrm{cat}} / K_{\mathrm{m}}$ of the lipase RCLpro-RML could be improved to $3833.4 \pm 2.6 \mathrm{~s}^{-1} \mathrm{mM}^{-1}$ after mutation. The increase in this value indicated the enhancement of the catalytic efficiency of the lipase. This suggested that the value of $k_{\text {cat }} / K_{\mathrm{m}}$ was of significance for improving the reaction efficiency of the enzyme and reducing the economic cost.

\section{Discussion}

At present, a variety of microorganisms capable of producing lipases have been found, and the characteristics of lipases produced by different types of microorganisms differed. The most common strains of productive bacteria include: Bacillus sp., Pseudomonas sp., Burkholderia sp., and Staphylococcus sp.; however, the wild strains isolated from the environment have low lipase activity. Bakir [34] isolated 201 strains of thermophilic bacteria from a hot spring in Aydin, Turkey, among which 22 were positive for lipase activity and only one (Anoxybacillus flavithermus HBB 134) was found to have a lipase activity of $19.925 \mathrm{U} / \mathrm{ml}$. By using a modified TB-TA plate, we realized the rapid isolation of Burkholderia sp. with an isolation rate of greater than $90 \%$. The production of lipases from submerged fermentation of Burkholderia sp. Bps1 reached $153.537 \mathrm{U} / \mathrm{ml}$ [35]. Shu et al. [36] reported that whole cell lipase ZYB002 exhibited good thermal stability and tolerance to organic solvents, and although it's the same as Bps-1 but belonging to the genus Burkholderia sp., the optimized lipase activity only reached $22.8 \mathrm{U} / \mathrm{ml}$. The current research revealed that B. gladioli Bps-1 has advantages including rapid growth, stable lipase production, and high yield.

The lipase Bps-1, purified through ethanol precipitation, ion-exchange chromatography using HiTrap $Q$ and Superdex 75 , had a molecular weight of $34.6 \mathrm{kDa}$. It exhibited the highest activity in the hydrolysis of $\mathrm{p}-\mathrm{NPC}_{16}$ at a $\mathrm{pH}$ of 8.5 and $65^{\circ} \mathrm{C}$. In addition, the values of $K_{\mathrm{m}}, k_{\text {cat }}$, and $k_{\text {cat }} / K_{\mathrm{m}}$ were $1.05,292.95 \mathrm{~s}^{-1}$, and $279 \mathrm{~s}^{-1} \mathrm{mM}^{-1}$, respectively. After incubating at a $\mathrm{pH}$ of 10 for $24 \mathrm{~h}$, the Bps-1 lipase retained $85 \%$ of its original enzyme activity. Furthermore, it also had a residual enzyme activity of $50 \%$ after incubation at $70^{\circ} \mathrm{C}$ for $1 \mathrm{~h}$. These indicate that it is a type of alkaline lipase conducive to thermal stability. Lee et al. [37] reported that the molecular weight of the lipase purified from Bacillus thermoleovorans ID-1 was $34 \mathrm{kDa}$, and the optimum temperature and $\mathrm{pH}$ for the lipase were 70 to $75^{\circ} \mathrm{C}$ and 7.5, respectively. Fifty percent of its activity was retained after being kept at $60^{\circ} \mathrm{C}$ for $1 \mathrm{~h}$ or at $70^{\circ} \mathrm{C}$ for $30 \mathrm{~min}$. The enzyme had excellent thermal stability but was incapable of tolerating a strong alkaline environment. Tang et al. [38] found that the molecular weight of the lipase produced by Bacillus coagulans ZJU318 was $32 \mathrm{kDa}$ and the optimum temperature and $\mathrm{pH}$ of the lipase were $45^{\circ} \mathrm{C}$ and 9.0. The lipase was stable at $7.0 \leq \mathrm{pH} \leq 10.0$ and was rapidly inactivated at temperatures of 40 to $50^{\circ} \mathrm{C} . \mathrm{Ag}^{+}, \mathrm{Cu}^{2+}, \mathrm{SDS}$, Brij 30, and Tween 80 inhibited the activity of the enzyme. Although the lipase from ZJU318 was an alkaline lipase, it had poor thermal stability. Compared with the above two enzymes, Bps-1 has a wider potential range of application.

Ogino [39] believed that the enzymes isolated from microorganisms of high tolerance to organic solvents probably show high tolerance to such solvents. They enriched the microbial samples in a medium containing 
$20 \%$ organic solvent, and finally screened a lipase derived from Pseudomonas aeruginosa LST-03 with a certain organic solvent tolerance, however, Shu et al. [40] only added a suitable amount of ampicillin and kanamycin to the directional screening medium, and obtained a total of 35 lipase-producing Burkholderia cepacia from the four rhizosphere soils. Among them, 15 strains were resistant to $10 \%$ by volume of benzene, hexane, and $n$-heptane. The lipase Bps-1 screened by the aforementioned method also has good short-chain alcohol tolerance and retains $110 \%$ of its enzyme activity after storage for $1 \mathrm{~h}$ in $30 \%(\mathrm{v} / \mathrm{v})$ ethanol. This reveals that the lipases produced by Burkholderia sp. have excellent stability in organic solvents and therefore can be widely applied in the field of organic synthesis.

In summary, the B. gladioli Bps- 1 isolated in this research grows rapidly and can yield large quantities of lipase compared with those reported elsewhere. The resulting lipase shows advantages such as high tolerance to alkaline and thermal environments and to short-chain alcohols. Therefore, the lipase can be used as a biocatalyst in the preparation of detergents, in the organic synthetic industry, for transesterification, and so on, and shows particularly high potential for use in the manufacture of biodiesel.

\section{Acknowledgment}

This work was supported by the Natural Science Foundation of Guangxi Province Youth Fund (Grant no. 2016GXNSFBA380177); the Guangxi Science and Technology Cooperation Programme (Grant no. 15104001-6); the National Natural Science Foundation of China (Grant no. 31560251), the Science Foundation of Guangxi Academy of Sciences (Grant no. 2017YJJ23013) and The Central Government Directs Special Funds for Local Science and Technology Development Projects (Grant no.ZY1949015).

\section{Conflict of Interest}

The authors have no financial conflicts of interest to declare.

\section{References}

1. Contesini FJ, Lopes DB, Macedo GA, da Graça Nascimento M, de Oliveira Carvalho P. 2010. Aspergillus sp. lipase: potential biocatalyst for industrial use. J. Mol. Catal. B-Enzym. 67: 163171.
2. Shu Z Y, Yang J K, Huang Y, Yan Y J. 2007. Resources and current state of lipases used in biodiesel production. Hubei Agric. Sci. 6: 64.

3. Fojan P, Jonson PH, Petersen MTN, Petersen SB. 2000. What distinguishes an esterase from a lipase: A novel structural approach. Biochimie 82: 1033-1041.

4. Winkler FK, D'Arcy A, Hunziker W. 1990. Structure of human pancreatic lipase. Nature 343: 771-774.

5. Zheng YY, Guo XH, Song NN, Li DC. 2011. Thermophilic lipase from Thermomyces lanuginosus : Gene cloning, expression and characterization. J. Mol. Catal. B Enzym. 69: 127-132.

6. Kohno M, Enatsu M, Funatsu J, Yoshiizumi M, Kugimiya W. 2001. Improvement of the optimum temperature of lipase activity for Rhizopus niveus by random mutagenesis and its structural interpretation. J. Biotechnol. 87: 203-210.

7. Jaeger KE, Ransac S, Dijkstra BW, Colson C, Van Heuvel M, Misset O. 1994. Bacterial lipases. FEMS Microbiol. Rev. 15: 29-63.

8. Yabuuchi E, Kosako Y, Oyaizu H, Yano I, Hotta H, Hashimoto Y, et al. 1992. Proposal of Burkholderia gen. nov. and transfer of seven species of the genus Pseudomonas homology group II to the new genus, with the type species Burkholderia cepacia (Palleroni and Holmes 1981) comb. nov. Microbiol. Immunol. 36: 1251-1275.

9. Yang W, He Y, Xu L, Zhang H, Yan Y. 2016. A new extracellular thermo-solvent-stable lipase from Burkholderia ubonensis SL-4: identification, characterization and application for biodiesel production. J. Mol. Catal. B Enzym. 126: 76-89.

10. Ungcharoenwiwat P, H-Kittikun A. 2015. Purification and characterization of lipase from Burkholderia sp. EQ3 isolated from wastewater from a canned fish factory and its application for the synthesis of wax esters. J. Mol. Catal. B Enzym. 115: 96-104.

11. Xie C, Wu B, Qin S, He B. 2016. A lipase with broad solvent stability from Burkholderia cepacia RQ3: isolation, characteristics and application for chiral resolution of 1-phenylethanol. Bioprocess Biosyst. Eng. 39: 59-66.

12. Ling $X \mathrm{M}$, Wang $\mathrm{XY}$, Ma $\mathrm{P}$, Yang $\mathrm{Y}$, Qin JM, Zhang $\mathrm{XJ}$, et al. 2016. Covalent immobilization of penicillin $G$ acylase onto $\mathrm{Fe}_{3} \mathrm{O}_{4} @$ chitosan magnetic nanoparticles. J. Microbiol. Biotechnol. 26: 829-836.

13. Wang XY, Jiang XP, Li Y, Zeng S, Zhang YW. 2015. Preparation Fe3O4@ chitosan magnetic particles for covalent immobilization of lipase from Thermomyces lanuginosus. Int. J. Biol. Macromol. 75: 44-50.

14. Xu M Q, Wang S S, Li L N,Gao J,Zhang Y W. 2018. Combined cross-linked enzyme aggregates as biocatalysts. Catalysts 8: 460.

15. Pencreac'h G, Baratti JC. 1997. Activity of Pseudomonas cepacia lipase in organic media is greatly enhanced after immobilization on a polypropylene support. Appl. Microbiol. Biotechnol. 47: 630-635. 
16. Gupta N, Rathi P, Gupta R. 2002. Simplified para-nitrophenyl palmitate assay for lipases and esterases. Anal. Biochem. 311: 98-99.

17. Singh R, Gupta N, Goswami VK, Gupta R. 2006. A simple activity staining protocol for lipases and esterases. Appl. Microbiol. Biotechnol. 70: 679-682.

18. Cao Y, Zhuang Y, Yao C, Wu B, He B. 2012. Purification and characterization of an organic solvent-stable lipase from Pseudomonas stutzeri LC2-8 and its application for efficient resolution of (R, S)-1-phenylethanol. Biochem. Eng. J. 64: 5560.

19. Hagedorn C, Gould WD, Bardinelli TR, Gustavson DR. 1987. A selective medium for enumeration and recovery of Pseudomonas cepacia biotypes from soil. Appl. Environl Microbiol. 53: 2265-2268.

20. Chakraborty K, Paulraj R. 2009. Purification and biochemical characterization of an extracellular lipase from Pseudomonas fluorescens MTCC 2421. J. Agric. Food Chem. 57: 3859.

21. Park DS, Oh HW, Heo SY, Jeong WJ, Shin DH, Bae KS, et al. 2007. Characterization of an extracellular lipase in Burkholderia sp. HY-10 isolated from a longicorn beetle. J. Microbiol. 45: 409.

22. Wang HK, Liu RJ, Lu FP, Wei Q, Jing S, Ma HJ. 2009. A novel alkaline and low-temperature lipase of Burkholderia cepacia isolated from Bohai in China for detergent formulation. Ann. Microbiol. 59: 105-110.

23. Chaiyaso T, Seesuriyachan P, Zimmermann W, Hkittikun A. 2012. Purification and characterization of lipase from newly isolated Burkholderia multivorans PSU-AH130 and its application for biodiesel production. Ann. Microbiol. 62: 1615-1624.

24. Lu Y, Lu F, Wang X, Bie X, Sun H, Wuyundalai, et al. 2009. Identification of bacteria producing a thermophilic lipase with positional non-specificity and characterization of the lipase. Ann. Microbiol. 59: 565-571.

25. Ji Q, Xiao S, BH Liu X. 2010. Purification and characterization of an organic solvent-tolerant lipase from Pseudomonas aeruginosa LX1 and its application for biodiesel production. J. Mol. Catal. B Enzym. 66: 264-269.

26. Patel V, Nambiar S, Madamwar D. 2014. An extracellular solvent stable alkaline lipase from Pseudomonas sp. DMVR46: Partial purification, characterization and application in nonaqueous environment. Process Biochem. 49: 1673-1681.

27. Aguilar C, Bertani I, Venturi V. 2003. Quorum-sensing system and stationary-phase sigma factor (rpoS) of the onion pathogen Burkholderia cepacia genomovar I type strain, ATCC 25416. Appl. Environ. Microbiol. 69: 1739-1747.
28. Dandavate V, Jinjala J, Keharia H, Madamwar D. 2009. Production, partial purification and characterization of organic solvent tolerant lipase from Burkholderia multivorans V2 and its application for ester synthesis. Bioresour. Technol. 100: 3374-3381.

29. Rahman RN, Baharum SN, Basri M, Salleh AB. 2005. Highyield purification of an organic solvent-tolerant lipase from Pseudomonas sp. strain S5. Anal. Biochem. 341: 267-274.

30. Snellman EA, Sullivan ER, Colwell RR. 2002. Purification and properties of the extracellular lipase, LipA, of Acinetobacter sp. RAG-1. Eur. J. Biochem. 269: 5771-5779.

31. Yu N, Yang Jc, Yin Gt, Li Rs, Zou Wt, He C. 2018. Identification and characterization of a novel esterase from Thauera sp. Biotechnol. Appl. Biochem. 65: 748-755.

32. Ai L, Huang Y, Wang C. 2018. Purification and characterization of halophilic lipase of Chromohalobacter sp. from ancient salt well. J. Basic Microbiol. 58: 647-657.

33. Wang Z, Lv P, Luo W, Yuan Z, He D. 2016. Expression in Pichia pastoris and characterization of Rhizomucor miehei lipases containing a new propeptide region. J. $f$ Gen. Appl. Microbiol. 62: 25-30.

34. Bakir ZB, Metin K. 2016. Purification and characterization of an alkali-thermostable lipase from thermophilic Anoxybacillus flavithermus HBB 134. J. Microbiol. Biotechnol. 26: 1087-1097.

35. Jing Z, Yanjing L, Yan Q, Naikun S, Yi L, Ge L, et al. 2018. Optimization of a molasses based fermentation medium for lipases from Burkholderia sp. Bps1 based on response surface methodology. Food Sci. Technol. Res. 24: 757-765.

36. Shu ZY, Wu JG, Cheng LX, Chen D, Jiang YM, Li X, et al. 2012. Production and characteristics of the whole-cell lipase from organic solvent tolerant Burkholderia sp. ZYB002. Appl. Biochem. Biotechnol. 166: 536-548.

37. Lee D, Koh Y, Kim K, Kim B, Choi H, Kim D, et al. 2005. Isolation and characterization of a thermophilic lipase from bacillus thermoleovorans ID-1. FEMS Microbiol. Lett. 13: 519530.

38. Tang L, Xia L. 2005. Purification and partial characterization of a lipase from Bacillus coagulans ZJU318. Appl. Biochem. Biotechnol. 125: 139-146.

39. Ogino H, Watanabe F, Yamada M, Nakagawa S, Hirose T, Noguchi A, et al. 1999. Purification and characterization of organic solvent-stable protease from organic solvent-tolerant Pseudomonas aeruginosa PST-01. J. Biosci. Bioeng. 87: 61-68.

40. Shu ZY, Lin RF, Jiang H, Zhang YF, Wang MZ, Huang JZ. 2009. A rapid and efficient method for directed screening of lipase-producing Burkholderia cepacia complex strains with organic solvent tolerance from rhizosphere. J. Biosci. Bioeng. 107: $658-661$ 